\title{
PROFIL PROGRAM PENDAMPINGAN SEBAGAI KEGIATAN PENGUAT DALAM PEMBELAJARAN BAHASA JEPANG DI KELAS III SD WIDIATMIKA JIMBARAN
}

\author{
I.D.G.O.A. Yasa', I.W. Sadyana², G.S. Hermawan ${ }^{3}$ \\ ${ }^{123}$ Jurusan Pendidikan Bahasa Jepang, Universitas Pendidikan Ganesha, Singaraja \\ e-mail: idwgdokaardaay@gmail.com, wayan.sadyana@undiksha.ac.id, satya.hermawan@undiksha.ac.id
}

\begin{abstract}
Abstrak
Penelitian ini bertujuan untuk mendeskripsikan profil program pendampingan pembelajaran bahasa Jepang di kelas III SD Widiatmika Jimbaran. Penelitian ini menggunakan teori kajian pembelajaran yang mengacu pada program pendampingan pembelajaran bahasa Jepang. Data akan dianalisis dengan menggunakan metode deskriptif kualitatif. Subjek penelitian ini adalah guru bahasa Jepang di SD Widiatmika Jimbaran. Objek penelitian ini adalah kegiatan belajar mengajar yang merupakan proses dari interaksi antara guru dan siswa. Data dikumpulkan dengan menggunakan metode observasi, wawancara dan dokumentasi. Hasil penelitian ini meliputi tiga hal, yaitu sasaran, strategi dan kendala-kendala dari program pendampingan pembelajaran bahasa Jepang di SD Widiatmika Jimbaran. Sasaran program pendampingan pembelajaran bahasa Jepang di SD Widiatmika Jimbaran meliputi aspek membaca, menulis, mendengar, berbicara dan pengetahuan budaya. Strategi program pendampingan pembelajaran bahasa Jepang yang digunakan adalah strategi lagu, tanya jawab dan ceramah. Kendala-kendala yang dihadapi dalam program pendampingan adalah guru program pendampingan dan kendala media pembelajaran.
\end{abstract}

Kata Kunci: pembelajaran, profil, program pendampingan, strategi pembelajaran

\section{要旨}

本研究の目的は、ジンバランウィディアットミカ私立小学校の三年生における日本語学習支援プログ ラムを分析することを目的としている。本研究の目的は、日本語学習支援プログラムを参照する学習 研究理論を使用している。データは、記述的な定性的方法を使用して分析される。研究の対象は、ジ ンバランウィディアットミカ私立小学校の日本語教師である。この研究の目的は、教師と学生の間の 相互作用のプロセスである教育と学習活動である。調査方法は、観察、インタビュー及び、文献調査 である。この研究の結果には 3 つは、ジンバランウィディアットミカ私立小学校の日本語学習伴奏プ ログラムの目標、日本語学習伴奏プログラムの目標を達成するための学習ストラテジーと日本語学習 伴奏プログラムの障害を明らかことである。分析した結果は、日本語学習の目標は、聞く力・読む力 ・話す力・書く力・文化の知識という 5 つの能力において、日本語能力を伸ばすことができることで ある。日本語学習の目標を達成するための学習ストラテジーは、歌ストラテジーと Q\&A ストラテジ 講義である。日本語学習支援プログラムは、教師の指導の欠如と学習メディアの制約である。

キーワード : 概要、学習、学習伴奏プログラム、学習ストラテジー

\section{Pendahuluan}

Kegiatan belajar mengajar (KBM) merupakan proses penyampaian ilmu atau transfer ilmu yang dilakukan oleh guru untuk siswa. Pada proses tersebut, guru memiliki tugas mengajar, membimbing, mengarahkan, menilai serta mengevaluasi siswa untuk mencapai tujuan pembelajaran. Dalam prosesnya di kelas, seorang guru harus bisa berkomunikasi secara baik dengan siswa. Selain itu, guru juga harus bisa menjadi penghubung komunikasi antar siswa sehingga komunikasi antar siswa dapat terjalin dengan baik. Komunikasi yang dilakukan harus menjurus pada komunikasi yang edukatif. Pada kegiatan belajar mengajar yang dilakukan, siswa diarahkan untuk mencapai tujuan tertentu. Oleh karena itu,sebelum 
melakukan kegiatan belajar mengajar, guru diwajibkan untuk membuat suatu rancangan kegiatan pengajaran yang dapat mendukung tercapainya tujuan tersebut.

Dalam kegiatan belajar mengajar, rancangan kegiatan pengajaran yang dibuat oleh guru biasanya menggunakan metode dan strategi tertentu. Penentuan rancangan tersebut tidak hanya berdasarkan materi yang diajarkan, tetapi juga dengan mempertimbangkan kondisi kelas dan siswa. Rancangan tersebut biasanya disusun secara sistematis dan memanfaatkan segala sesuatu yang dapat mendukung kegiatan pengajaran. Namun dalam praktiknya, walaupun guru sudah merancang kegiatan pengajaran dan menggunakannya sebagai panduan dalam mengajar, adanya kemungkinan masalah mengenai siswa yang tidak dapat mencapai tujuan pembelajaran tetap ada. Hal ini dapat terjadi akibat adanya masalah-masalah tertentu seperti kurangnya waktu pengajaran, jumlah siswa yang terlalu banyak dalam satu kelas (kelas besar), dan lain sebagainya. Oleh karena itu, guru diharapkan dapat membuat rencana lain sebagai inovasi untuk menutupi kekurangan tersebut sehingga seluruh siswa dapat mencapai tujuan pembelajaran.

Program pendampingan pembelajaran adalah proses pemberian bantuan berupa penguatan pada pelaksanaan pembelajaran. Pada program ini, suatu kegiatan dilaksanakan secara sistematis dan sesuai dengan aturan yang telah ditentukan. Program pendampingan pembelajaran dilakukan sesuai dengan rencana yang telah ditentukan agar tidak menimbulkan permasalahan dalam pelaksanaan program tersebut (Istiningsih, 2008:85).

Program pendampingan pembelajaran diharapkan dapat dijadikan pedoman atau landasan dalam mengembangkan potensi yang dimiliki oleh siswa. Ketercapaian program pendampingan pembelajaran bermuara pada life skill yang up to date, karena program pendampingan difungsikan untuk lebih memaksimalkan pembelajaran reguler yang kurang kondusif. Tujuannya adalah membuat para siswa dapat menerapkan teori-teori yang sudah mereka pelajari secara langsung dan menumbuhkan kepercayaan diri peserta didik untuk mengaplikasikan teori-teori tersebut dalam kegiatan sehari-hari. Selain itu, program ini juga untuk membantu siswa agar dapat beradaptasi dengan baik dalam situasi pembelajaran, sehingga setiap peserta didik dapat belajar dengan efisien sesuai dengan kemampuan yang dimiliki dan mencapai perkembangan yang optimal.

SD Widiatmika Jimbaran adalah sekolah swasta yang menerapkan program pendampingan pembelajaran yang memberikan semua kesempatan keseluruh peserta didik dengan latarbelakang dan kemampuan yang berbeda untuk melakukan program pendampingan pembelajaran. SD Widiatmika Jimbaran merupakan sekolah swasta yang menjadi satu-satunya sekolah dasar yang mengadakan program pendampingan pembelajaran. Selain itu sekolah tersebut memiliki visi dan misi yaitu menyelenggarakan kegiatan pembelajaran yang PAIKEM (pembelajaran partisipatif, aktif, inovatif, kreatif, efektif dan menyenangkan). Itu sesuai dengan apa yang dicanangkan dalam program pendampingan pembelajaran. Program pendampingan ini dilaksanakan tiga kali dalam seminggu dengan durasi waktu dua jam per pertemuan. Dalam proses pendampingan ini harus diawali dengan sumber bertujuan agar siswa dapat mempelajari teori dan tata bahasa dengan baik. Sedangkan sumber ajar dalam proses program pendampingan pembelajaran bahasa Jepang berupa, buku ajar, lagu, gambar dan vidio. Sehingga proses pendampingan bisa berjalan secara kondusif.

Berdasarkan hasil wawancara yang dilakukan pada tanggal 10 Desember 2018 kepada guru bahasa Jepang dalam program pendampingan pembelajaran, tujuan diadakannya program pendampingan pembelajaran bahasa Jepang di SD Widiatmika Jimbaran adalah sebagai penambah wawasan dan untuk meningakatkan daya kreadibilitas siswa. Selain itu, tujuan program pendampingan pembelajaran bahasa Jepang merupakan salah satu upaya sekolah dalam pemberian kesempatan pada siswa untuk mengembangkan dan mengekspresikan diri sesuai dengan kebutuhan setiap siswa. 
Program pendampingan pembelajaran bahasa Jepang harus disesuaikan dengan karakteristik dan gaya belajar siswa. Rancangan pendampingan bahasa Jepang berdasarkan pada kondisi siswa sebagai subjek belajar. Selain itu, memanfaatkan sarana dan teknologi yang ada dalam proses pembelajaran perlu diperhatikan. Pemanfaatan tersebut juga harus disesuaikan dengan karakteristik pembelajaran. Pada prinsipnya tujuan program pendampingan pembelajaran bahasa Jepang yang dilakukan di sekolah adalah agar para siswa terampil dalam menyimak, berbicara, membaca, dan menulis. Di dalam program ini juga mengenalkan tentang budaya Jepang. Penggunaan media atau alat peraga dalam kegiatan pendampingan ini mempengaruhi cara belajar siswa dan memberikan peluang kepada siswa untuk belajar lebih baik, sehingga tujuan program ini akan semakin lebih mudah tercapai.

Dalam prosesnya, program pendampingan ini diawali dengan pemilihan sumber ajar dengan tujuan agar siswa dapat memperoleh ilmu secara maksimal. Sumber ajar yang diberikan kepada siswa dalam pembelajaran reguler berupa buku ajar yang sudah disediakan oleh sekolah dan bersifat teoritis agar siswa dapat mempelajari teori dan tata bahasa dengan baik. Sedangkan sumber ajar dalam program pendampingan menggunakan buku ajar dan media berupa lagu, gambar dan video, sehingga proses pendampingan bisa berjalan secara kondusif dan siswa dapat mempraktikkan teori yang telah dipelajari pada pembelajaran reguler dengan baik.

Sesuai dengan program pendampingan di SD Widiatmika Jimbaran. Program pendampingan kelas bahasa Jepang difungsikan untuk meningkatkan pengetahuan dan daya kreativitas bagi peserta didik.Seperti, meningkatkan aspek berbicara, menulis, mendengarkan dan membaca. Dalam proses kegiatan pendampingan berlangsung guru dapat mencegah dan mengatasi masalah yang ditimbulkan oleh siswa, walaupun adapun kendala yang dihadapi oleh guru saat proses pendampingan berlangsung. Seperti, adanya keributan antara sesama siswa karena kurangnya pengawasan guru. Guru memberikan penguatan dan teguran ketika siswa menunjukkan tingkah laku yang kurang baik. Dalam kegiatan proses pendampingan guru menunjukan sikap yang tanggap dengan mendekati siswa jika ada yang ribut. Ini menandakan kesiagaan, minat dan perhatian guru terhadap siswanya.

Dalam proses kegiatan progam pendampingan pembelajaran bahasa Jepang berlangsung guru dapat mencegah dan mengatasi masalah yang ditimbulkan oleh siswa, walaupun ada kendala yang dihadapi oleh guru saat proses pendampingan berlangsung. Seperti, adanya keributan antara sesama siswa karena kurangnya pengawasan guru. Guru memberikan penguatan dan teguran ketika siswa menunjukkan tingkah laku yang kurang baik. Dalam kegiatan proses pendampingan guru menunjukan sikap yang tanggap dengan mendekati siswa jika ada yang ribut. Ini menandakan kesiagaan, minat dan perhatian guru terhadap siswanya.

Penelitian terkait profil program pendampingan sebagai penguat pembelajaran bahasa Jepang salah satunya oleh Purrosani (2015). Selain itu penelitian terkait program pendampingan pembelajaran juga telah dilakukan oleh Roehati (2019). Namun Armini dan Yanti (2018) juga mendeskripsikan tentang profil strategi pembelajaran bahasa Jepang dengan memiliki perbedaan yang mengkhususkan penelitian pada satu jenis keterampilan bahasa.

Sehingga atas dasar inilah penulis bermaksud untuk melaksanakan penelitian mengenai pembelajaran bahasa Jepang di Kelas III SD Widiatmika Jimbaran yang dituangkan dalam judul "Profil Program Pendampingan Sebagai Penguat Pembelajaran Bahasa Jepang Di Kelas III SD Widiatmika Jimbaran". Dari latar belakang yang telah dipaparkan, dapat dirumuskan permasalahan adalah sebagai berikut.

1. Apa sasaran program pendampingn pembelajaran bahasa Jepang di SD Widiatmika Jimbaran? 
2. Apa dan bagaimana strategi program pendampingan sebagai penguat pembelajaran bahasa Jepang di SD Widiatmika Jimbaran?

3. Apa kendala-kendala yang dihadapi dalam program pendampingan pembelajaran bahasa Jepang di SD Widiatmika Jimbaran?

Penelitian ini menggunkan beberapa teori yang mendukung proses penelitian. landasan teori yang digunakan adalah 1) kajian teori pembelajaran yang mangacu pada program pendampingan, 2) kajian teori strategi pembelajaran bahasa asing 3) kajian teori bahasa Jepang dasar, 3) metode pembelajaran bahasa asing dan 4) Kajian teori tentang bermain.

\section{Metode}

\section{Metode pengumpulan data}

Metode pengumpulan data yang digunakan dalam penelitian ini adalah metode observasi, wawancara dan dokumentasi. Metode observasi digunakan untuk mengumpulkan data dan menunjang pengambilan data. Kegunaan dari metode observasi adalah untuk 1) gambaran nyata mengenai suasana program pendampingan pembelajaran bahasa Jepang 2) mengetahui dokumen program pendampingan pembelajaran bahasa Jepang di kelas III SD Widiatmika Jimbaran.

Dalam penelitian ini, peneliti menggunakan metode wawancara semi terstruktur karena format wawancara yang berkaitan dengan program pendampingan pembelajaran bahasa Jepang di kelas III SD Widiatmika Jimbaran, telah disiapkan sebelum wawancara dilakukan, namun terdapat pertanyaan tambahan mengikuti pertanyaan yang telah disiapkan untuk mendapatkan suatu informasi yang lebih terperinci dan akurat.

Metode dokumentasi diperlukan untuk mengetahui dokumen program pendampingan pembelajaran bahasa Jepang di kelas. Peneliti akan mengumpulkan data berupa bahan ajar atau materi yang digunakan, data prestasi siswa, lembar kerja siswa dan foto dokumentasi pelaksanaan program pendampingan pembelajaran di ruang kelas.

Sumber data dalam penelitian ini adalah guru program pendampingan pembelajaran bahasa Jepang di kelas III SD Widiatmika Jimbaran.

\section{Metode dan Teknik Analisis Data}

Teknik analisis data dalam penelitian ini dibedakan menjadi dua yang meliputi, teknik analisis data kualitatif. Prosedur yang dilaksanakan dalam menganalisis data dalam penelitian ini meliputi 1) tabulasi data, 2) reduksi data, 3) deskripsi data, 4) klasifikasi data, 5) penarikan kesimpulan.

Analasis dimulai dari data hasil observasi, wawancara dan dokumentasi akan digabungkan dan diklasifikasikan berdasarkan profil program pendampingan pembelajaran bahasa Jepang, baik sasaran program pendampingan pembelajaran bahasa Jepang, factor yang mendasari penggunaan strategi dalam program pendampingan pembelajaran bahasa Jepang dan kendala-kendala yang ditemukan.

Kemudian dilanjutkan dengan penyederhanaan data yang diperoleh dari hasil observasi yang dilaksanakan dalam program pendampingan pembelajaran bahasa Jepang di kelas III SD Widiatmika Jimbaran. Dalam tahap ini, seluruh data yang diperoleh melalui observasi dan wawancara dideskripsikan sesuai dengan fakta yang ditemukan dilapangan. Data-data yang diperoleh digolongkan berdasrkan sub-sub masalah. Setelah proses tersebut barulah peneliti dapat menarik kesimpulan. Kesimpulan ini merupakan jawaban dari segala permasalahan penelitian. 


\section{Hasil dan Pembahasan Hasil Penelitian}

Data dalam penelitian ini diperoleh melalui observasi, wawancara, dan dokumentasi. Observasi dilakukan sebanyak tiga kali di Kelas III SD Widiatmika Jimbaran. Wawancara yang digunakan adalah wawancara semi terstruktur untuk mengetahui lebih mendalam mengenai sasaran program pendampingan pembelajaran bahasa Jepang, strategi yang digunakan dalam program pendampingan pembelajaran bahasa Jepang dan kendalakendala yang dihadapi dalam program pendampingan pembelajaran bahasa Jepang di Kelas III.

\section{Data Hasil Observasi}

Hasil dari observasi pertama dilakukan di ruang kelas III A, B dan C sebanyak 109 siswa. Pada hari Senin, 4 November 2019, pada pukul 14.30- 15.30 wita dengan materi lagu shiawase nara te o tatakou dengan versi bahasa Inggris if you're happy and you know it clap your hands. Kegiatan awal pembelajaran guru memasuki ruang kelas, dan mengucapkan salam sapaan (aisatsu) dalam bahasa Jepang Konichiwa こんにちは (konnichiwa), siswa membalas dengan jawaban yang sama yakni こにちは (konnichiwa), guru melakukan sapaan berikutnya お元気ですか (ogenki desu ka?), siswa membalas dengan jawaban yang sama yakni はい、げんきです (hai, genki desu) kemudian siswa melakukan absen kehadirannya selama 5 menit. Setelah itu, Guru memperkenalkan materi sebuah lagu Bahasa Jepang. Dalam kegiatan bernyanyi guru membuat sebuah kelompok untuk menyanyikan lagu tersebut di depan kelas. Pemilihan lagu tersebut dikarenakan sudah dikenal sebelumnya baik dari lirik maupun nada. Lagu yang yaitu lagu shiawase nara te 0 tatakou dengan versi bahasa Inggris if you're happy and you know it clap your hands.

Guru memulai inti pembelajaran Pertama guru pendampingan Bahasa Jepang memberikan pengenalan dan penjelasan terkait makna lagu yang akan dinyanyikan yaitu Shiawase Nara Te o Tatakou dengan versi Bahasa Inggris if you're happy and you know it clap your hands. Guru memulai materi dengan menuliskan judul lagu dipapan tulis dengan menggunakan huruf alfabet.

Hasil dari observasi kedua dilakukan di ruang kelas III A, B dan C sebanyak 109 siswa. Pada hari Selasa, 12 November 2019 pada pukul 14.30- 15.30 wita dengan materi menggambar dan mewarnai anime Naruto. Kegiatan pembelajaran Guru memperkenalkan materi gambar tentang anime Naruto. Dalam kegiatan ini guru memberikan selebaran kertas gambar untuk menggambar. Setelah itu guru membuat sebuah kelompok. Pemilihan anime sebagai media dikarenakan lebih memudahkan siswa untuk meningkatkan daya kreatifitas mereka selain itu juga mereka dapat mengetahui berbagai macam anime untuk diwarnai. Gambar anime yang digunakan merupakan anime karakter Jepang yang sudah mereka kenal, selain mewarnai mereka juga harus mengetahui warna apa saja yang mereka gunakan dan bisa menyebutkan warna tersebut dengan menggunakan bahasa Jepang.

Guru memulai inti pembelajaran Guru menuliskan kosakata yang dipelajari dalam materi mewarnai anime yakni Guru menuliskan nama-nama warna untuk memudahkan mereka mengetahui warna apa saja yang dipergunakan saat mewarnai anime tersebut. Guru juga menanyakan kepada siswa tentang warna yang mereka gunakan. Guru menanyakan kepada siswa dengan menggunakan bahasa Indonesia untuk memudahkan dalam tanya dan jawab.

Hasil dari observasi kedua dilakukan di ruang kelas III A, B dan C sebanyak 109 siswa. Pada hari Rabu, 20 November 2019 pada pukul 14.30- 15.30 wita dengan materi film anime sprited away. Kegiatan awal pembelajaran Guru memperkenalkan materi film anime sprited away. Dalam kegiatan ini guru memberikan sebuah film anime dan mencari nilai-nilai positif dari anime tersebut. Setelah itu guru membuat sebuah kelompok. Pemilihan film 
anime sebagai media dikarenakan lebih memudahkan siswa untuk mengambarkan dan mencari nilai-nilai positif yang terdapat difilm tersebut.

Guru memulai inti pembelajaran Guru memberikan intruksi kepada siswa topik hari ini yaitu menonton film anime. Setelah itu, guru meperkenalkan film anime yang akan ditonton yaitu film anime Sprited Away. Guru hanya memberikan bagian adegan film yang mengandung pesan dan nilai-nilai karakter didalam film tersebut.

\section{Data Hasil Wawancara}

Berdasarkan hasil wawancara, guru program pendampingan bahasa Jepang di kelas III SD Widitmika Jimbaran. Program pendampingan pembelajaran bahasa Jepang ini diberikan pada seluruh siswa disemua tingkat kelas dari kelas I sampe dengan kelas $\mathrm{VI}$. Tujuan dibentuknya program pendampingan bahasa jepang adalah sebagai upaya menambah ketramfilan dan daya kreativitas siswa. Sasaran yang ingin dicapai dalam kegiatan program pendampingan bahasa Jepang memiliki kesamaan dengan tujuan pembelajaran regular pada umumnya yaitu diharapkan siswa mampu menguasai materi dari program pendampingan tersebut. Selain itu, sasaran diadakannya program pendampingan bahasa Jepang di SD Widiatmika Jimbaran juga sebagai upaya pengenalan budaya Jepang itu sendiri. Dalam program pendampingan pembelajaran bahasa Jepang, guru memfokuskan siswa dalam mengikuti lomba-lomba dalam keterampilan bahasa Jepang. Upaya pencapaian sasaran pembelajaran bahasa Jepang sebagai program pendampingan diusahakan oleh guru dengan menggunakan berbagai cara salah satunya pengadaan media pembelajaran yang digunakan guru. Media pembelajaran berupa lagu bahasa Jepang, gambar karakter anime, film anime dan lain sebagainya disiapkan secara inisiatif oleh guru yang bersumber dari pemahan yang sudah didapat. Materi pembelajaran dirancang sedemikian rupa oleh guru program pendamping.

\section{Sasaran Program Pendampingan Pembelajaran Bahasa Jepang Di Kelas III SD Widiatmika Jimbaran}

Dalam proses program pendampingan guru tetap menggunakan cara yang bertujuan tercapainya proses program pendampingan dalam pembelajaran. Sasaran pertama yaitu pada aspek berbicara. Kemampuan ini merupakan kemampuan yang paling ditekankan dalam pembelajran ketika dalam bahasa Jepang. Kemampuan berbicara meliputi kemampuan siswa dalam melafalkan bunyi, kata dan ungkapan dalam ungkapan sapaan yaitu dalam penggunaan (aisatsu), setiap mengawali pembelajaran dalam bahasa Jepang yang memunculkan respon siswa dalam bahasa Jepang. Untuk melatih siswa dalam pengucapan bahasa Jepang juga terlihat dari kegiatan bernyanyi menggunakan bahasa Jepang. Dalam pengucapan bahasa Jepang, selain itu dengan penggunaan lagu, siswa juga mendapatkan penambahan kosakata baru. Guru mengajarkan cara pengucapan yang baik dan benar, beserta arti dari kosakata yang ada dalam lagu.

Pada aspek mendengarkan yang berkaitan dengan kemampuan siswa dalam menangkap kosakata bahasa Jepang dan membedakan cara pelafalan kosakat dalam bahasa Jepang. Kemampuan ini dilatih dengan adanya seperti animasi film Anime yang memudahkan siswa untuk masuk dalam aspek mendengarkan. Dalam kegiatan ini, siswa diintruksikan untuk mencari nilai-nilai positif yang terdapat dalam film tersebut dan memperhatikan teman yang sedang membacakan hasil pekerjaan kelompok di depan kelas. Setelah pembacaan hasil latihan siswa selesai, guru menguji pendengaran siswa dengan cara mengajukan pertanyaan.

Pada aspek menulis yaitu siswa mampu menulis kosakata maupun kalimat dengan menggunakan huruf Hiragana, Katakana maupun Romaji. Kemampuan menulis dilatih setiap pembelajaran bahasa Jepang, guru menekan kan pada kemampuan menulis bahasa Jepang dengan menggunakan huruf Romaji. Hal ini terlihat pada kegiatan komunikasi tulisan yang 
dilakukan oleh guru hanya menggunakan huruf Hiragana, Katakana dan Romaji. Sehingga siswa lebih mudah untuk mencatatnya.

\section{Strategi Yang Digunakan Dalam Program Pendampingan Pembelajaran Bahasa Jepang Di Kelas III SD Widiatmika Jimbaran}

Strategi dalam program pendampingan pembelajaran bahasa Jepang di SD Widiatmika Jimbaran merupakan pembelajaran yang berpusat pada siswa. Seluruh komponen pembelajaran berpatokan pada siswa, baik dari segi pengajaran maupun pemilihan materi. Dalam proses pembelajaran bahasa Jepang di SD Widiatmika Jimbaran guru terlihat memaksimalkan tahapan bahasa Jepang dasar yaitu pertama 導入(dounyuu) atau latihan pengenalan dan kedua 基本練習(kihon renshuu) atau latihan dasar sedangkan untuk tahapan 応用練習 (ouyou renshuu) atau latihan penggunaan dalam pembelajaran bahasa Jepang di SD Widiatmika Jimbaran sudah terlaksana.

Tahap 導入(dounyuu) atau latihan pengenalan dilakukan dengan kegiatan pengenalan kosakata baru, pola kalimat dan contoh kalimat dengan menggunakan bahasa Indonesia (bahasa ibu). Pengenalan kosakata menggunakan media tambahan yaitu e kaado (kartu gambar)

Tahap 基本練習(kihon renshuu) atau latihan dasar dilakukan dengan penggunaan strategi drill terkait kosakata dan pola kalimat yang telah dipelajari. Selain itu guru juga memberikan pengayaan dengan pemberian latihan pembuatan contoh kalimat baru kepada siswa. Pada tahap ini terdapat kegiatan 反復練習 (hanpukurenshuu) atau latihan pengulangan kosakata baru, hal ini dilakukan oleh guru agar siswa memiliki ingatan yang kuat terhadap kosakata baru.

Tahap 応用練習 (ouyou renshuu) atau latihan penggunaan sangat ditekankan oleh guru dalam program pendampingan pembelajaran bahasa Jepang di SD Widiatmika Jimbaran.

Menurut hasil observasi yang telah dilakukan sebanyak tiga kali dapat disimpulkan bahwa guru di SD Widiatmika Jimbaran menggunakan Strategi penggunaan lagu, tanya jawab, dan ceramah dalam proses program pendampingan pembelajaran bahasa Jepang.

\section{Lagu}

Strategi penggunaan lagu selalu dilakukan pada tahap sebelum pembelajaran dimulai.Kegiatan bernyanyi dilakukan secara bersama dengan tujuan membangun semangat siswa dalam memulai pembelajaran. Lagu yang dinyanyikan shiawase nara te o tatakou terjemaha lagu if you happy and you know clap your hands.

\section{Strategi tanya jawab}

Sering dilakukan oleh guru dalam mengulangi materi pelajaran (fukushuu) materi sebelumnya. Tanya jawab berupa pemberian pertanyaan terkait materi sebelumnya mewarnai anime. Selain itu strategi tanya jawab juga dilakuakn sebagai upaya membangun rasa ketertarikan siswa terhadap materi yang akan dipelajari.

\section{Ceramah}

Strategi ceramah digunakan dalam menjelasakan apa pola kalimat beserta contoh kalimat. Untuk mengurangi tingkat kebosanan siswa dalam mendengarkan penjelasan guru mengenai film anime, guru memvariasikan dengan strategi tanya jawab. Pertanyaan diusahakan dengan pertanyan menarik terkait film anime yang dapat mengarahkan kembalii fokus siswa. Setelah penjelasan kalimat dilakukan dengan menggunakan strategi ceramah, guru memberikan pengayaan berupa latihan pembuatan pola kalimat. 


\section{Kendala-Kendala Yang Dihadapi Dalam Program Pendampingan Pembelajaran Bahasa Jepang Di Kelas III SD Widiatmika Jimbaran}

Berdasarkan hasil penelitian, terdapat beberapa kendala yang dihadapi dalam program pendampingan pembelajaran bahasa Jepang sebagai berikut.

\section{Kendala mengenai guru program pendampingan}

Kurangnya guru program pendampingan menyebabkan kondisi di kelas menjadi kurang kondusif. Hal ini terlihat dari kurangnya pengawasan terhadap masing-masing kelas yang menyebabkan siswa menjadi tidak kondusif dalam melakukan pembelajaran. Dalam program pendampingan terdapat dua guru untuk mengajar. sedangkan terdapat tiga kelas yang harus diajarkan. Guru yang profesional adalah guru yang mampu mengatur kelas dengan baik. Pengaturan kelas yang baik merupakan upaya yang dilakukan oleh guru untuk menciptakan kondisi belajar yang kondusif yang memungkin siswa untuk belajar di kelas. Guru mengatasi kendala ini dengan berusaha memantau di masing-masing kelas program pendampingan pembelajaran bahasa Jepang.

\section{Kendala mengenai media pembelajaran}

Dalam pembelajaran diperlukan sebuah media yang dapat menunjang pembelajaran yang merupakan salah satu hal yang penting untuk meningkatkan minat siswa dalam belajar dan jika hanya menggunakan metode yang menoton siswa akan cepat bosan. Fasilitas yang disediakan oleh pihak sekolah seperti LCD juga merupakan kendala bagi guru. Sekolah menyediakan fasilitas berupa LCD di setiap kelas, kadang-kadang tidak dapat berfungsi dengan baik sehingga proses pembelajaran menjadi kurang kondisif. Selain itu, kurang ada persiapan dalam pembuatan media pembelajaran. Guru mengatasi kendala dalam penggunaan media pembelajaran dengan berusaha sebisa mungkin menggunakan media baik itu media gambar ataupun dari media yang lain.

\section{Simpulan dan Saran}

Berdasarkan hasil penelitian dan pembahasan mengenai profil strategi pembelajaran bahasa Jepang di SD Widiatmika Jimbaran dapat disimpulkan sebagai berikut.

1. Sasaran program pendampingn pembelajaran bahasa Jepang di SD Widiatmika Jimbaran Meliputi 1) aspek berbicara, 2) aspek mendengarkan, 3) aspek Menulis , 4) aspek membaca dan 5) Pengetahuan tentang Jepang secara umum baik berupa Bahasa, gaya hidup maupun budaya Jepang.

2. Strategi program pendampingan pembelajaran bahasa Jepang di SD Widiatmika adalah pembelajaran yang berpusat pada siswa meliputi 1) Strategi penggunaan lagu, 2) tanya jawab dan 3) ceramah. Strategi penggunaan lagu selalu dilakukan pada tahap sebelum kegiatan pembelajaran di mulai. Kegiatan bernyanyi dilakukan secara bersama-sama dengan tujuan membangun semangat siswa dalam memulai pembelajaran. Strategi tanya jawab sering dilakukan oleh guru dalam mengulangi materi pembelajaran (fukushuu) materi sebelumnya. Strategi tanya jawab merupakan kegiatan 応用練習 (ouyou renshuu) latihan merespon dan menjawab terkait kosakata baru berupa pemberian pertanyaan terkait materi yang diajarkan. Selain itu strategi tanya jawab juga dilakukan sebagai upaya membangun rasa ketertarikan siswa terhadap materi yang akan dipelajari. Strategi ceramah digunakan dalam menjelaskan pola kalimat beserta contoh kalimat disertai terjemahan dalam bahasa Indonesia.

3. Kendala-kendala yang dihadapi dalam program pendampingan pembelajaran bahasa Jepang meliputi 1) kendala mengenai guru pendamping dan 2) kendala mengenai media pembelajaran. 
Saran

1. Bagi guru diharapkan kedepannya dapat meningkatkan keterampilannya khususnya dalam program pendampingan pembelajaran Bahasa Jepang. Selain itu guru seharusnya lebih memanfaatkan media dan mencari bahan pelajaran yang lebih menarik agar siswa lebih semangat dan mempunyai antusias yang lebih tinggi.

2. Guru sebaiknya menyeimbangkan pelajaran bahasa dan budaya Jepang. Karena dalam tujuan pegadaan program pendampingan pembelajaran bahasa Jepang di SD Widiatmika Jimbaran diharapkan dapat memperoleh wawasan mengenai informasi dan budaya Jepang

3. Penelitian ini diharapkan mampu meneliti lebih dalam program pendampingan pembelajaran bahasa Jepang dan Memfokuskan juga materi pembelajaran yang terdapat di program pendampingan.

\section{Daftar Rujukan}

Armini, Ni Putu Yuli, dkk. 2018. "Profil Strategi Pembelajaran Bahasa Jepang di Kelas 4 SD Saraswati Tabanan". Tersedia pada https://ejournal.undiksha.ac.id/index.php/JJPBJ/article/view/14949

Arifin, Zaenal. 2012. Evaluasi Pembelajaran. Bandung: PT. Remaja Rosdakarya

Istiningsih, 2008. Model Pembelajaran Berbasis Among Dalam Penyuluhan. Yogyakarta: UPT-UNY

Matsumoto, 2007. Shokyuu o Oshieru. Tokyo: The Japan Foundation

Mulyasa, 2002. Kurikulum Berbasis Kompetensi, Konsep, Karakteristik dan Implementasi. Bandung: Remaja Rosda Karya

Purrosani, Adityo. 2015. "Program Pendampingan Pembelajaran Luar Sekolah Berbasis Wisata Pada Anak SD". Yogyakarta: UNY

Padmadewi, Ni Nyoman. 2012. Strategi Pembelajaran Bahasa. Singaraja: Undiksha Press

Oxford, Rebecca L. 2017. "Relationship between Second Language Learning Strategies and Language Proficiency in The Context of Learner Autonomy and Self-Regulation". Revista Canaria de Estudios Ingleses, Nomor 30 (hIm.109-126)

Rohaeti, 2019. "Program Pendampingan Kearifan Lokal Desa Adat Senaru Dalam Meningkatkan Motivasi Belajar". Journal Abdimas (Lombok Utara): IKIP Siliwangi 